\title{
Nursing and spirituality in front of geriatric patients in AIDS termination
}

\begin{abstract}
Goal: to reflect the Nursing fence and the spirituality in front of the geriatric patients in terminality of AIDS.

Method: It is a descriptive, qualitative study, of the type reflection scientific method for gerontological bases of nursing.

Results and discussion: It is estimated that there are 36.9 million people living with HIV/ AIDS worldwide, with about 2 million new cases and 1.2 million deaths annually. Brazil, the approximate number is 781 thousand people living with HIV/AIDS, with 12.449 deaths recorded in 2014, where the geriatric patients in terminality are absurd.

Conclusion: The nursing team is constantly activated for patients with a high severity and mortality profile. Patients followed by the nursing team in the face of spirituality and the termination of AIDS are evaluated and had a significant reduction of potentially inappropriate interventions.
\end{abstract}

Keywords: nursing, geriatric, AIDS, care, spirituality
Volume 4 Issue 2 - 2019

Ana Beatriz dos Santos, Jonas Borba da Silva, Angélica Helena Tito Fernandes, Ingrid Maria Gomes Moura, Alcione Maria de Anastácio

Oliveira, Andreia Alves Monteiro, Aline

Andressa Coelho de Souto, Erika Patrícia da Silva, Arrhenius Nobre Almeida Chaves, Nathaly Alves Cavalcante, Laíze Samara dos Santos, Layla Lívia Maranhão Costa, Jivaldo Gonçalves Ferreira, Yalle Laryssa Florencio Silva, Jordânia Jeflat Lima da Silva, Fernanda Caroline Florêncio, Geraldo Vicente Nunes Neto

Nurse, postgraduate in intensive care with emphasis on urgency and emergency, Harvard University, USA

Correspondence: Geraldo Vicente Nunes Neto, Department of Nurse, postgraduate in intensive care with emphasis on urgency and emergency, Harvard University, USA, Tel 33333333 , Email nursing_harvard@hotmail.com

Received: March 07, 2019 | Published: March 15, 2019

\section{Introduction}

Technical-scientific progress has contributed to the recovery and healing of severely ill individuals. Elsewhere, the number of people with chronic and debilitating diseases for whom there are no more therapeutic possibilities for cure is increasing and, throughout the course of the disease, there are very specific physical, psychological, social and spiritual fragilities and limitations that expose the individual and family members to a situation of intense pain and suffering, such as HIV/AIDS. In this way, the process of living has.

HIV/AIDS is a serious, progressive, incurable and potentially life-threatening disease, even in the era of highly active antiretroviral therapy (HAART). In addition, patients with HIV/AIDS may also have significant comorbidities, such as viral hepatitis, tuberculosis, syphilis, anemia, depression, arterial hypertension, drug allergies, nephropathies, diabetes, among others. It is therefore imperative to provide good quality of life to the patient without therapeutic possibility of cure with palliative care, emphasizing an approach that fully meets their needs. ${ }^{2}$

Nursing and spirituality towards geriatric patients in AIDS terminality plays an important role in the accreditation of the patient and his/her family. Once they put in the team all their strength to continue the process of care.

Palliative care is recommended because it contributes to the control of the physical, emotional, spiritual and social suffering of the patient and his or her family. In addition, it promotes the relief of pain and symptoms associated with the pathology, from the beginning of its therapy. From this perspective, they aim to attend the human being by understanding it as a holistic being, encompassing it in its biopsychosocial and spiritual dimensions. ${ }^{4}$

In this perspective, this modality of care highlights the importance of a multidisciplinary and interdisciplinary approach in the treatment of the patient outside the healing therapeutic resources, in order to provide harmonious and convergent assistance to him and his family. The minimum palliative care team should be composed of a physician, nurse, psychologist and social worker, as well as the assistance of other professionals such as physiotherapist, occupational therapist, pharmacist, nutritionist, chaplain, dentist, speech therapist, among others, who must be properly trained on the philosophy and palliative practice of caring. ${ }^{5}$

Geriatric Nursing, as a member of the multidisciplinary palliative team, is essential for the palliative care of patients and their families, since the essence of their professional practice is care, since it combines art and science with a care that provides shelter, comfort and support, premises Nursing and palliation. A study about the knowledge and practice of palliative care, particularly in the area of geriatric Nursing, attests that there are few researches that approach the subject.This fact points out the relevance of new studies that can contribute to the socialization of knowledge about the importance of the topic addressed. ${ }^{6}$

Therefore, this study aimed to: to reflect the Nursing fence and the spirituality in front of the geriatric patients in terminality of AIDS. Having as guiding question: How are the methodological bases of data about the subject under study? 


\section{Method}

It is a descriptive, qualitative, narrative-type study that should be understood as a way of understand the human experience. It is a study of lived histories and counted, because "a true narrative research is a dynamic process of living and telling stories, and reliving and recounting stories, not just those who the participants count, but also those of the researchers. ${ }^{7}$

According to the authors, who develop their work of narrative research as a method of study, the role of the researcher is to interpret the texts and, from them, to create a new text. The data obtained in the can be collected orally and/or written, researcher to decide which of them best suits the profile of their study. Reflecting on education, we see narrative research as a possibility of interesting study, since education and life are interconnected. ${ }^{8}$

The narrative perspective has become so closely related to treated as texts heard or counted, however, the stories of Narrative researchers show that narrative research is much more than listening to stories, it is a way of life, it is a way of life, it is known that narrative research is a learning process so that can be thought in a narrative way, so that one looks at one's life, while lived narratively. ${ }^{9}$

For the work with the narrative research methodology some terms are highlighted, such as personal and social to deal with the interaction; past, present and future to develop the notion of continuity and place to mark the situation. The object of study of narrative research is the narrated stories. People need to be understood as individuals, who are always in interaction and always inserted in a social context. This set of terms form a three-dimensional space for narrative inquiry. ${ }^{10}$

Regarding the description of the scientific methodology, the international literature comments on the historical milestones of nursing research in Brazil, highlighting: the 1950 Census and the Nursing Resources and Needs Survey (1956-1958) by ABEn, the Thesis of Gtete de Alcântara (1963), the 160th Congress of Nursing, with the theme "Nursing and Research" (1964). However, the dissemination of knowledge and professional experiences began in the 1930s, with the creation by ABEn of the "Annaes de Enfermagem" (Nursing Annaes) (1932), which were renamed Geriatric Nursing Magazine in $1954 .{ }^{11}$

Therefore, bibliometric analysis was performed to characterization of the selected studies. Posteriorly, the concepts discussed in each article were extracted and of interest of the researchers. The works were compared and grouped by content similarity, in the form of empirical categories, being constructed in scientific stanzas for a better understanding and finalization of the work. ${ }^{12}$

The method was organized analytically and structurally, with key words, scientific methodological organizations for geriatric nursing, spirituality and the terminology of AIDS against potentialities.

\section{Results and discussion}

Population aging is a worldwide phenomenon with regional peculiarities that include differences in gender, income, schooling and access to health services. In developed countries, the specificities of this population have been more effectively considered by the public sectors to establish strategies to better meet the health needs of this population segment. Concomitant with the aging of the population is the so-called "epidemiological transition", which represents the change in the morbidity and mortality pattern, from which chronic diseases become more importante. ${ }^{13}$
Parallel to these events, in the 1980s, an infectious urban disease arises: the Acquired Immunodeficiency Syndrome, AIDS or AIDS. Transmitted vertically, during childbirth or breastfeeding, sharing contaminated needles and syringes, blood transfusions, and sexual intercourse, the disease, which originated from the action of the HIV virus on defense cells over the years, appeared to be distant from the elderly . And, initially, in fact, few were affected. ${ }^{14}$

In Brazil, only four cases of AIDS among the elderly were registered during the first five years of the epidemic. Initially, the misconception that the infection was restricted to some "at-risk groups" - such as men who have sex with men, hemophiliacs, injecting drug users and sex workers, did not include the elderly. Such ideas are convergent with prejudices manifest strongly at the beginning of the phenomenon of the AIDS epidemic and remain in different spheres of society until today. ${ }^{15}$

However, the scientific literature and health services have identified that new HIV-positive profiles have emerged, triggering strong criticism of the idea of "risk groups" and focusing on combating "risk behaviors" such as sexual practice without condom use and syringe sharing. Subsequently, the concept of vulnerability was constructed after a clearer epidemiological and biological, epidemiological and psychosocial aspects, which considers not only individual practices but also social, historical and cultural characteristics that lead populations to be more vulnerable by not adopting prevention methods. ${ }^{16}$

We try to comment on the categories emerged per decade denoting the tendency of the authors when referring to the question of human spirituality and highlight some sections of articles so that the reader can understand this tendency. For example geriatric nursing facing spirituality in geriatric patients with HIV / AIDS in terminality. It is a very important subject and little prevalent in the scientific methodology. The staff is very hardworking and capable of providing care to these patients. ${ }^{17}$ Some articles bring the question of spirituality as a value to ensure the charitable and almost superhuman nature that permeates to be a nurse. ${ }^{18}$

We have identified trends in this that denote a spirituality more linked to religion in the the first two decades analyzed and that, along the others, it adds reflections of ethical character, bioethical, philosophical and tentative understanding of the phenomena of spirituality not only as basic human need of the clientele, but from the point of the professional himself. The study of the articles reveals fascinating, especially for the fact that we have found references to very current themes in articles dating from 20 to 30 years behind. Texts in which nurses were already concerned quality care to the human being in terminality (now called palliative care); the review of nursing curricula with the aim of developing a more holistic and generalist formation; themes of Bioethics as dysthanasia, euthanasia, the defense and maintenance of dignity, autonomy and identity of the client, among others. ${ }^{19}$

\section{Conclusion}

In this way, learning to deal with losses in a chronic illness context, such as AIDS, is a challenge for both patients and their families, as well as the team multiprofessional approach that is more closely linked to end-of-life care. The need to replace acculturation that links this epidemic with death and dying is emphasized by a culture that shows daily living with the AIDS virus in a perspective of decronicidad. Anseiase that this study can subsidize new investigations pertaining to the said subject, as well as to stimulate further reflection on the importance of $\mathrm{CP}$ practitioners in the elderly patients affected by the 
disease. It is important to clarify the scarcity of material on nursing and spirituality in the face of the terminality of geriatric HIV/AIDS patients and what further research should be done.

\section{Acknowledgments}

None.

\section{Conflicts of interest}

No conflict of interest has been declared by the author.

\section{References}

1. Meirelles BHS, Silva DMGV, Vieira FMA, et al. Percepções da qualidade de vida de pessoas com HIV/Aids. Rev Rene. 2010;3(11):68-76.

2. Santos ECM, França JRI, Lopes F. Qualidade de vida de pessoas vivendo com HIV/aids em São Paulo. Rev Saúde Pública. 2007;2(41).

3. Caracilo, JMM. Shimma E. Adesão da teoria a pratica: experiências bem sucedidas no estado de São Paulo. São Paulo: Centro de Referência e Treinamento DST/AIDS; 2007.

4. Ministério da saúde. secretaria de vigilância em saúde. Programa Nacional de DST e Aids. Boletim epidemiológico aids - DST 2013; versão preliminar. Acesso em: 16 de janeiro de, Brasil; 2014.

5. Ministério da saúde. secretaria de vigilância em saúde. programa nacional de DST e Aids. Acesso em: 26 de novembro de, Brasil, 2013.

6. Ministério da Saúde. Secretaria Municipal de Saúde de João Pessoa. Relatório: Tendências da aids. Programa DST/aids. João Pessoa, Secretaria Estadual da Saúde; Brasil. 2013.

7. Santos NJS. Mulheres HIV positivas reprodução e sexualidade. Rev Saúde Pública. 2002;4(36):12-23.

8. Santos NJS. AAids entre as Mulheres no Estado de São Paulo. In: Parker R, Galvão J, editors. organizadores.Quebrando o silêncio: mulheres e AIDS no Brasil. Rio de Janeiro: Relume-Dumará; 1996.
9. Zimpel RR, Fleck MPA. Qualidade de vida em pacientes com HIV/ aids: conceitos gerais e resultados de um estudo brasileiro. Avaliação de qualidade de vida: guia para profissionais de saúde. Ed. Artmed; 2008.

10. Conselho Nacional de Saúde. Resolução n 466, de 12 de dezembro de 2012. Aprova normas regulamentadoras de pesquisas envolvendo seres humanos. Brasília: Diário Oficial da União; Brasil. 2013.

11. Simon V, Ho DD, Abdool KQ. HIVAIDS epidemiology,pathogenesis, prevention and treatment. Lancet. 2006 5;368(9534):489-504.

12. Parker R, Galvão J. Quebrando o Silêncio: Mulheres e Aids no Brasil. Rio de Janeiro: Relume-Dumará, ABIA; 1996.

13. Barbosa RM. HIV/AIDS, Transmissão heterossexual e métodos de prevenção controlados pelas mulheres. in: saúde sexual e reprodutiva, colação aBIA. Rio de Janeiro; 2000.

14. Nascimento AMG, Barbosa CS, Medrado B. Mulheres de camaragibe: representação social sobre a vulnerabilidade feminina em tempos de AIDS. Ver Bras Saúde Mater Infant. 5(1):77-86.

15. Reis KR, Santos CB, Dantas RAS, Gir E. Qualidade de vida, aspectos socidemográficos e de sexualidade de pessoas vivendo com HIV/aids. Texto e contexto Enferm. 2011;3(20):565-575.

16. Reis KR. Qualidade de vida de portadores do HIV/Aids: Influencia dos fatores demográficos, clínicos e psicossociais. Tese (Doutorado) - Escola de enfermagem de ribeirão preto da universidade de são paulo; 2008.

17. Gil NLM, Souza LR. Qualidade de Vida de Indivíduos Infectados pelo HIV relacionada com características sociodemográficas e clínicas. Ciênc cuid Saúde. 2010;4(9).

18. IBGE. Instituto brasileiro de geografia e estatística - censo demográfico 2013 - Resultados da Paraíba; 2014.

19. Galvão MTG, Cerqueira ATAR, Machado JM. Avaliação da qualidade de vida de mulheres com HIV/AIDS através do HAT-QoL. Cad Saude Publica. 2004;20(2):430-437. 